\title{
Omnipresence and the Location of the Immaterial ${ }^{*}$
}

\author{
Ross D. Inman \\ Saint Louis University
}

\begin{abstract}
I first offer a broad taxonomy of models of divine omnipresence in the Christian tradition, both past and present. I then examine the recent model proposed by Hud Hudson $(2009,2014)$ and Alexander Pruss (2013) - ubiquitous entension - and flag a worry with their account that stems from predominant analyses of the concept of 'material object'. I then attempt to show that ubiquitous entension has a rich Latin medieval precedent in the work of Augusine and Anselm. I argue that the model of omnipresence explicated by Augustine and Anselm has the resources to avoid the noted worry by offering an alternative account of the divide between the immaterial and the material. I conclude by considering a few alternative analyses of 'material object' that make conceptual room for a contemporary Christian theist to follow suite in thinking that at least some immaterial entities are literally spatially located when relating to the denizens of spacetime.
\end{abstract}

At the heart of many a theistic metaphysic is the view that an exhaustive inventory of reality consists of both material and immaterial entities, and that these two domains interact in some way or other. There is, however, surprisingly little discussion at the intersection of contemporary metaphysics and philosophical theology concerning the precise nature and relationship between the material and the immaterial and its bearing on Christian theology.

This was not always the case. Medieval philosophical reflection was replete with discussion on the nature of the relationship between God, angels, and the human soul and the material domain. In fact, according to Robert Pasnau (2011a), the medieval scholastics were largely in agreement that immaterial entities, though lacking in material content are, strictly speaking, spatially located or present in some sense or other when relating to material reality. The question that preoccupied medieval philosophical theologians, then, was not whether such entities were spatially located or present in their dealings with material beings, but rather, how they were located as such. This, of course, assumes an understanding of the material-immaterial divide that is largely foreign to the contemporary context. Yet it is one that is both philosophically interesting, theologically fruitful, and by my lights worthy of serious consideration once again.

\footnotetext{
*For a representative writing sample please consult the introduction, §2, and §4.
} 
In this paper I want to explore the prospects of following on the heels of the medievals in thinking of immaterial beings, God and the human soul in particular, as being spatially located or present in some sense to the material domain. I begin by offering a brief taxonomy of various models of omnipresence that have been offered both in the history of Christian philosophical theology as well as the contemporary literature. I then turn to examine a recent account of omnipresence in terms of ubiquitous spatial occupation or location as well as the underlying metaphysics it employs. After highlighting a point of tension for such a view with standard analyses of the concept of a 'material object', I offer a historical sampling of Latin medieval views regarding the nature of the relationship between God and the human soul to space. I conclude by noting how such views help carve out a range of alternative analyses of 'material object' that leave conceptual room for a contemporary theist to follow suite in thinking that at least some immaterial entities are spatially located or present to the physical domain.

\section{Omnipresence: A Taxonomy}

To say that God is omnipresent is to say that God is present or located at each and every place (where 'place' in what follows will serve as a generic place-holder for either an existing entity -a region of space-or simply a material object together with the spatiotemporal or distance relations it stands in to other material objects). But what exactly does it mean to say that God, an immaterial being, is present or located at a particular place? Here it appears that we are already in very deep waters indeed.

In the most general terms, models of omnipresence can be classified according to whether God is taken to be located or present at a place in either a fundamental or a derivative sense. Roughly, for an entity to be located at some place fundamentally is for it to be located at that place in its own right; or in other words: the locative facts about where the entity is located obtain in virtue of facts about the entity itself, together with the places and the primitive 'is located at' relation that ties them to those places. On the other hand, an entity's being located at some place derivatively amounts to the claim that it is located in virtue of standing in some particular relation or relations to a distinct entity, where the latter is itself located at the place in the fundamental sense; or, the locative facts concerning where the entity is located obtain in virtue of the locative facts about where some distinct entity is located fundamentally, together with the various relations it bears to the entity in question.

Taking "is located at" as our primitive we can state these two varieties of location as follows (where ' $\mathrm{p}$ ' stands for some place):

Fundamental Location: $x$ is located at $p$ fundamentally $=_{d f} x$ is located at $p$ in its own right, i.e. not in virtue of standing in a relation(s), R(s), to some distinct $y$ that is located at $p$ in its own right. 
Derivative Location: $x$ is located at $p$ derivatively $=_{d f} x$ is located at $p$ in virtue of standing in some relation(s), $\mathrm{R}(\mathrm{s})$, to some distinct entity, $y$, where $y$ is located at $p$ fundamentally.

Material objects, for example, are constituents of reality that are located at a place in the fundamental sense; trees, tables, and tigers are spatially located at a place in their own right in that they themselves bear the "located at" relation to the place in question.

Before applying the above framework to divine omnipresence, it may be helpful to consider the following non-theological example illustrating the distinction between Fundamental Location and Derivative Location. Those who defend an ontology of immanent universals maintain that such entities exist 'in' their instances in that they are located where the particulars that instantiate them are located. Consider, for example, the universal charge -1 that is shared by all electrons. As an immanent universal, the property charge -1 is (wholly) multiply located where each and every individual electron is located.

Now consider an individual electron that is located at some place $p$. For the proponent of immanent universals, the location of charge -1 at $p$ can be construed in one of two ways: either (i) charge -1 is located at $p$ only in the sense that it is instantiated by an electron that is itself located at $p$, or (ii) charge -1 is located at $p$ in the sense that it is located at $p$ in its own right, i.e. not in virtue of bearing a relation to something that is located at $p$ in its own right. Many friends of immanent universals are inclined to think that such properties are spatially located in the fundamental rather than the derivative sense. ${ }^{1}$

Note further the reductive nature of Derivative Location: an entity's being located at a particular place is nothing more than its standing in some relation or relations to a distinct entity that is itself located at that place in the fundamental sense. To endorse Fundamental Location, then, amounts to the claim that $x$ 's standing in $\mathrm{R}$ to some distinct entity that is located at a place in the fundamental sense is neither necessary, sufficient, or neither necessary nor sufficient for its being located at that place. As stated, Fundamental Location and Derivative Location are mutually exclusive: an object cannot be both fundamentally and derivatively located at the same place at the same time.

With the above notions of Fundamental Location and Derivative Location in hand, we can broadly divide models of divine omnipresence along the following lines. Let " $L_{d}$ " stand for Derivative Location, " $L_{f}$ " for Fundamental Location, and read " $L(G o d, p)$ " as "God is located at $p$ ":

(FO) Fundamental Omnipresence: $(\forall p)\left(p\right.$ is a place $\left.\rightarrow L_{f}(G o d, p)\right)$

(DO) Derivative Omnipresence: $(\forall p)\left(p\right.$ is a place $\left.\rightarrow L_{d}(G o d, p)\right)$

As was the case with Non-Derivative Location and Derivative Location, FO and DO are mutually exclusive models of divine omnipresence. An informal test for distinguishing DO and FO models would be if the model entails that God, considered apart

\footnotetext{
${ }^{1}$ See O'Leary-Hawthorne and Cover (1998) as well as Gilmore (2003).
} 
from his standing in some relation or relations to objects that are themselves located at $p$ fundamentally, could nevertheless be located at $p$. If so, then you have an FO model; if not, then a DO model.

A list of thinkers who are commonly thought to endorse an account of omnipresence along the lines of DO include Anselm, Aquinas, Descartes, Leibniz, and Jonathan Edwards in his later writings (to name just a few). DO models differ as to how they construe the particular relation or relations (R or Rs) in which God stands to entities that are located at a place in the fundamental sense. ${ }^{2}$

One common interpretation of Anselm, for instance, characterizes R exclusively in epistemic terms, namely, God's immediate knowledge or awareness of the goings on at every place. ${ }^{3}$ Along similar lines, a standard reading of Aquinas on omnipresence is that he closely adheres to a common medieval formula originating with Peter Lombard in terms of (i) God's immediate causal activity at every place, (ii) God's immediate knowledge or awareness of every place, and (iii) God's essence or substance existing at every place. Many interpreters read Aquinas as reducing clause (iii) to clause (i), namely God's directly causally sustaining in existence each and every creature in a place. $^{4}$

The overwhelming majority of work on divine omnipresence in contemporary philosophical theology consists of variants of DO. ${ }^{5}$ The likes of Swinburne (1993), Hoffman and Rosenkrantz (2002), Taliaferro (1994), Wierenga (2010), and Craig and Moreland (2003) all broadly follow Aquinas in unpacking Rs in terms of God's standing in immediate (basic) causal relations as well as his immediate knowledge of the ongoings at every place. The recent work of Eleonore Stump $(2010,2013)$ aims to defend a DO model which includes the notion of shared or joint attention as a more fine-grained epistemic condition on divine omnipresence, in addition to God's immediate causal activity and cognitive awareness of every place and its occupants. ${ }^{6}$

\footnotetext{
${ }^{2}$ See Anselm (1998, ch. 20-22), Aquinas (1974: III, q. 68), Descartes (1985: 372-373), Leibniz (1989: 683, 690) and Jonathan Edwards (1955: 183-184).

${ }^{3}$ See Blount (1997), Wierenga (1988), and Hudson (2009). Although see Conn (2011), Leftow (1989), Pasnau (2011a), and Zagzebski (2013) for an alternative reading of Anselm on omnipresence.

${ }^{4}$ See Cross (2003), Swinburne (1993), and Wierenga (2010), and Wainwright (2009) for this reading of Aquinas.

${ }^{5}$ Contemporary philosophers of religion who endorse a DO model of omnipresence include Richard Swinburne, Peter van Inwagen, Joshua Hoffman and Gary S. Rosenkrantz, William Wainwright, Edward Wierenga, Charles Taliaferro, Eleonore Stump, Norman Kretzmann, William Lane Craig, and J.P. Moreland.

${ }^{6}$ See Stump (2010: 117), “God's having direct and unmediated cognitive and causal contact with everything in creation is still insufficient for divine omnipresence. In order for God to be omnipresent, that is, in order for God to be always and everywhere present, it also needs to be the case that God is always and everywhere in a position to share attention with any creature able and willing to share attention with God." However, Stump is clear both that shared attention is an epistemic state between persons (which would suggest that God fails to be present in places where there are no (non-divine) persons, and whether or not God is omnipresent in the sense she defines is partly determined by the state or condition of the creature (p. 117).
} 
One interesting thing to note in passing here is that it is difficult to see how on a DO model omnipresence is a distinct attribute over and above divine omnipotence, omniscience, omnibenevolence, or a combination of these divine attributes. For this reason, the proponent of a DO model might consider omnipresence to be reducible to or "nothing over and above" one of the above attributes or conjunction thereof.7

FO models of omnipresence, on the other hand, are often thought to be few and far between in the history of Christian philosophical theology. Yet FO models were particularly common in the later medieval and early modern period, most notably in the thought of Nicole Oresme, Isaac Newton, and the Cambridge Platonist Henry More. ${ }^{8}$ More (1995), for instance, grounded God's attribute of omnipresence in God's being identical to space, where he understood space to be uncreated, necessary, omnipresent, and existing $a$ se. Without going so far as to identify God with space, Newton (1934: 545 ) was of the opinion that (absolute) space was inextricably bound up with the existence of God that while "he is not duration or space, but he endures and is present. He endures forever, and is everywhere present; and by existing always and everywhere, he constitutes duration and space. Since every particle of space is always...certainly the Maker and Lord of all things cannot be never and nowhere." Since God's existence alone accounts for both the existence of absolute space as well as God's being present to each point of absolute space, his existing of necessity demands that God be omnipresent to absolute space from all eternity. ${ }^{9}$

\footnotetext{
${ }^{7}$ Along these lines, consider the following remark by Robert Adams (1994:124) concerning Leibniz's DO account of omnipresence in terms of God's exercising immediate causal action at a place: "In his later years, Leibniz understands God's immensity as omnipresence and seems favorably disposed to the Scholastic reduction of God's presence in a place to 'immediate operation' on things that are in that place. This suggests the view that immensity is not a divine perfection distinct from omnipotence."

${ }^{8}$ As I hope to show in much more detail elsewhere, I consider FO models to be much more prominent in the Christian tradition than is commonly thought. There is a case to be made that even the likes of early modern philosophers Nicolas Malebranche and John Locke as well as theologians John Wesley and the early Jonathan Edwards endorsed FO models of omnipresence. The first three thinkers rely on the principle that an agent, whether created or uncreated, had to first be present at a place for it to be able to act or perceive at that place. In responding to an account of omnipresence characterized solely in terms of God's causal operation at each place, Malebranche (1997) (speaking through the character Theodore in his Dialogues on Metaphysics and Religion), states "What kind of reality is God's operation as distinguished and separated from his substance?...Now, if the act by which God produces or conserves this chair is here, surely God is here himself; and if he is here, he must be here completely and thus in all the other respects in which he operates" (133, dialogue 8, sec. 5); Locke (1975): "Spirits, as well as Bodies, cannot operate, but where they are" (Essays, bk. 2, ch. 23, sec. 19); Wesley (1991): "And these sufficiently prove his omnipresence; which may be farther proved from this consideration: God acts everywhere, and, therefore, is everywhere; for it is an utter impossibility that any being, created or uncreated, should work where it is not..." (Sermon 111 "On the Omnipresence of God"). The early Edwards (1955), most likely reflecting the influence of Henry More, claims that "space is necessary, eternal, infinite, and omnipresent. But I had as good speak plain, I have already said as much as that space is God." (Of Being, 19)

${ }^{9}$ Strangely enough, Newton thinks that "no being exists or can exist which is not related to space in some way. God is everywhere, created minds are somewhere, and body is in the space it occupies; and whatever is neither everywhere nor anywhere does not exist" (1962: 103). Yet God's being everywhere
} 
Those who defend a model of omnipresence along the lines of FO are a rare breed in contemporary analytic philosophical theology. There is one rather obvious reason why this may be the case. To maintain that God is located at every place in the fundamental sense is to claim that God is located everywhere, but not in virtue of his direct causal or cognitive contact with creatures that are themselves located in the fundamental sense. But what other sense of location or presence could possibly characterize an immaterial being other than the derivative variety in terms of basic causal or epistemic relations? It seems that a more robust and immediate form of location or presence along the lines required by FO models threatens to undermine both the immateriality and the transcendence of God. On first pass, then, it appears that the only way for immaterial beings in general to be located is for them to be located in the derivative sense.

Be that as it may, there are several contemporary philosophers and theologians who defend a variant of an FO model of omnipresence including Hud Hudson $(2009,2014)$, Alexander Pruss (2013), Robert Oakes (2006), and Luco J. Van Den Brom (1993). As we will see in much more detail below, Hudson and Pruss construe God's omnipresence as his being wholly spatially located at each region of spacetime in a particular kind of way (entension). Oakes, on the other hand, adopts the quasi-Newtonian line that God is everywhere present precisely because his existence constitutes the existence of space itself, that God is "maximally immanent in space-and, indeed, necessarily so: [since] space is an essential aspect of God" (175). Van Den Brom, in what looks to be the only book-length treatment on omnipresence in the last fifty years, defends the view that God is present at each place in our three-dimensional space in virtue of being spatially extended in his own higher-dimensional space, a hyperspace in which our own threedimensional space is embedded.

What unifies the above FO models is that each affirm that God is located at every place in his own right, and not in virtue of his standing in some immediate causal or epistemic relation to objects that are located in their own right. In other words, the locative facts about where God is located obtain in virtue of facts about God himself, together with the places and the primitive 'is located at' relation that relates God to those places. On FO models, omnipresence is independent of any further causal or epistemic (or any other) relations God might stand in to the denizens of spacetime, who are themselves located in the fundamental sense. Consequently, for those who defend a variant of FO, omnipresence is a distinct and non-derivative attribute of God and thereby irreducible to omnipotence, omniscience, omnibenevolence or the like.

There are two important things to note in passing regarding the above general models of omnipresence at play in the contemporary literature. First, there is an overarching consensus in contemporary work on divine omnipresence that what I am calling Derivative Location corresponds exclusively to non-spatial location, and that Funda-

present in such a way, for Newton, is no mere function of his causal operation at every place: "He is omnipresent not only virtually but also substantially; for action requires substance...It is agreed that the supreme God necessarily exists, and by the same necessity he is always and everywhere" (1999: 941-942). 
mental Location corresponds exclusively to spatial location. For the vast majority of contemporary philosophers and theologians who defend a DO model of omnipresence, while God is genuinely located at each and every place in virtue of either his immediate causal activity or knowledge or a combination of the two, this variety of location or presence is best understood in a non-literal sense; God is literally nowhere when present to the material occupants of spacetime. Hoffman and Rosenkrantz (2002: 41) state this view nicely: "We conclude that since God is not spatially located, there is no literal sense in which he could be omnipresent."

There are, however, a handful of medieval and early modern scholars who reject the above claim that Derivative Location and Fundamental Location neatly map on to the distinction between non-spatial and spatial location (respectively) when it comes to the development of omnipresence in the Christian tradition. ${ }^{10}$ It is argued that a plausible historical case can be made that even many of the DO models of omnipresence purportedly advanced by medieval and early modern philosophers are best thought of along the lines of God's being literally spatially located at or present to every place. As Jeffrey Brower (2014: 224-226) has recently noted, even Aquinas denies that "the mere possession of spatial location is sufficient for being a material object, since he thinks even God and the angels can be said to have spatial location" (225). While God is everywhere present in virtue of his direct causal and epistemic contact with each object that is located at a place fundamentally, it may be argued that even this variety of location was widely thought to be a genuine form of spatial location. ${ }^{11}$

Second, while FO and DO models are strictly incompatible models of omnipresence, it is entirely consistent for FO models to incorporate the notion that God stands in both direct causal and epistemic relations to creatures that are themselves fundamentally located at a place, and even that these types of relations (however coarse or fine-grained) factor into an exhaustive account of God's interaction with material reality. Part of what is at stake between FO and DO models of omnipresence is whether or not the attribute of omnipresence in particular is reducible to God's standing in such relations to material beings; proponents of FO models answer in the negative, those of DO models in the affirmative. While the FO proponent may question the reducibility of divine omnipresence to such relations, they are nevertheless free to help themselves to these or any other relations in order to provide a comprehensive and theologically adequate account of divine action and presence in the world (e.g., conservation, concurrence,

\footnotetext{
${ }^{10}$ See Pasnau (2011a, 2011b), Reid (2008), Brower (2014:224-226), Grant (1981), Goris (2009), Adams (2006), Muller (2003). Muller (2003: 343), for example, sums up theological reflection on divine omnipresence in Reformed Orthodoxy from the period between ca. 1565-1725 as follows: "God's immensity and omnipresence do not indicate a physical transcendence of physical space, but a categorical transcendence of spatiality" and "the divine immensity and omnipresence place God extra mundum ["outside the world"] in the sense of being beyond all physical limitation, not in the sense of being physically distanced from the world order."

${ }^{11}$ Even more, however, is the fact that some of these same scholars call into question standard characterizations of the Christian tradition as largely favoring an DO as opposed to an FO model of divine omnipresence.
} 
Eucharistic presence, indwelling of the Holy Spirit, etc.).

\section{Omnipresence as Ubiquitous Entension}

With the above taxonomy in hand, I now want to turn to examine an FO model of omnipresence recently advanced by both Hud Hudson $(2009,2014)$ and Alexander Pruss (2013), what Hudson refers to as "ubiquitous entension." I'll begin by unpacking some of the requisite metaphysics undergirding their view and then flag an untoward theological implication of their account stemming from predominant analyses of the concept of 'material object.'

Within the past few years, analytic metaphysics has seen a resurgence of interest in the variety of location or occupation relations that tie material objects to the places where they are located. On its surface, talk of 'places' smacks of a substantivalist view of space, the view that places exist independently of their contents and are in no way reducible to or derivative upon distance relations between material objects, as the relationalist maintains. While some are of the opinion that substantivalism has achieved something of a consensus among philosophers of physics for good reason, others are hopeful that talk of 'places' or 'locations' can be adequately paraphrased into a suitable relationalist framework. Though I myself lean more towards a substantival view of space, I intend to remain as neutral as possible as to how much ontological weight one ought to assign to talk of 'places' or 'locations' in what follows.

Informally, we may begin by saying that an object $o$ is located or present at a place $p$ if $p$ is not completely free of $o$. So, for instance, I am located in my office (where I use 'office' here to denote a particular place for illustrative purposes) in that my office is not completely free of me when I sit at my office desk, when I reach my arm out into the hallway to get the attention of my colleague, or when I reach my arm into my office window from the outside. Now say that I am entirely located in my office just in case I am in my office and I am nowhere outside of my office; I am exclusively in my office such that every place outside my office is completely free of me. The above example of my reaching my arm into my office window from the outside is a case of my being partly located in my office, one of my proper parts is entirely located in my office. Lastly, I am wholly located in my office just in case all of me is located in my office, there is no proper part of me that is not located in my office.

Following Hudson (2005: 99), we can define the following location relations (once again taking "is located at" as primitive):

$x$ is entirely located at $p=_{d f} x$ is located at $p$ and there is no place disjoint from $p$ at which $x$ is located.

$x$ is partly located at $p={ }_{d f} x$ has a proper part entirely located at $p$.

$x$ is wholly located at $p={ }_{d f} x$ is located at $p$ and there is no proper part of $x$ not located at $p$. 
Here I need to say a bit about the difference between an object's being entirely located and its being wholly located at a place, as the two are often conflated. ${ }^{12}$ In so far as it denotes exclusivity of location, my being entirely located in my office excludes my being located at any place that is disjoint from my office; if I am entirely in my office, I am nowhere else. On the other hand, my being wholly located in my office in no way excludes the possibility of my also being wholly located at a distinct, non-overlapping place in space; that is, it allows for the possibility of multi-location.

On the assumption that places can stand in part-whole relations to one another (places can have other places as proper parts, i.e. proper subplaces), we can define the notion of an object's entending and pertending a place in space:

$x$ pertends $p={ }_{d f} x$ is an object that is entirely located at an extended (nonpoint sized) place $p$, and for each proper subplace of $p, p^{*}, x$ has a proper part entirely located at $p^{*}$.

$x$ entends $p={ }_{d f} x$ is an object that is wholly and entirely located at an extended (non-point sized) place $p$, and for each proper subplace of $p, p^{*}, x$ is wholly located at $p^{*}$.

For an object to pertend in space is for it to be exclusively located at an extended place and for each of its proper parts to be 'spread out' or distributed across each of the proper subplaces of that place. My body, for instance, is entirely located at an extended place (right here and not on a beach in Bermuda), yet it is distributed across space in that it is partly located where my right arm is, and partly located where my head is, etc.

Now consider an object's entending a place in space. Roughly, for an object to entend is for all of it (without remainder) to be exclusively located at an extended place, and for all of it (without remainder) to be located at each of the proper subplaces of that place. Entending objects are not 'spread out' or distributed across space such that they are partly located or present at distinct, non-overlapping places; rather, for each of the places where they are located, they are wholly located at both the places themselves as well as at each of the proper parts of those places. ${ }^{13}$

Both Hud Hudson $(2009,2014)$ and Alexander Pruss (2013) have found in the relation of entension renewed prospects for shedding light on the divine attribute of om-

\footnotetext{
${ }^{12}$ Helm (1980), for instance, makes the following claim: "A second thing that it seems to mean is that God cannot be wholly present at two or more separated places at once. It seems to be a conceptual truth about any individual in space that it cannot be wholly present in two places at once." Here Helm collapses the distinction between an object's being entirely located at a region (there and nowhere else) and its being wholly located at a region (every proper part of the object is there, without remainder). If the denial of multi-location is a conceptual truth as Helm suspects, then entension (which entails but is not entailed by multi-location) is ruled out from the start.

${ }^{13}$ Note that while entension entails multi-location - an item cannot entend in space without being multi-located in space - the converse does not seem to hold in so far as an object that is multi-located at two distinct places, $\mathrm{p} 1$ and p2, need not be wholly located at each of the subplaces of $\mathrm{p} 1$ and $\mathrm{p} 2$.
} 
nipresence. ${ }^{14}$ They both suggest that divine omnipresence is plausibly construed in terms of ubiquitous entension: that God is wholly and entirely located at the maximally inclusive place, presumably the whole of spacetime itself, and is wholly located at each of that places proper subplaces (every proper subplace of spacetime).

Recall the two-fold definition of entension above. Given that the whole of spacetime itself encompasses every place whatsoever, it is clear that there is no place disjoint from it at which God is located. Moreover, the second clause of the definition is automatically satisfied if one takes God to be devoid of proper parts. On this view, in so far as God has no proper parts at all, he fails to have distinct parts spread out over the various subplaces of space. If one takes God to have proper parts, then God would be wholly located at every subplace of space in so far as every one of His proper parts would be located at every subplace of space.

In response to what he calls the problem of incorporeality, the question as to how something can occupy a place in space and fail to be material, Hudson argues that an untoward consequence of the ubiquitous entension model is that God turns out to be a material object, embodied in the whole of spacetime.

The untoward implication turns on Hudson's occupation analysis of the concept of 'material object' stated as follows:

Occupation: $x$ is a material object $=_{d f} x$ occupies a place in space. ${ }^{15}$

Hudson prefers to bite the bullet of God's being a material object rather than part with his preferred analysis of 'material object.' He notes:

My own view of the matter is that anything that occupies a region is a material object, and that the occupier inherits the shape, size, dimensionality, topology, and boundaries of the region in which it is entirely located. Anyone similarly attracted to the simple occupancy analysis of 'material object' and these related theses has a bullet to bite if he wants to endorse an entension-based reading of omnipresence...to be fair, however, the simple occupancy analysis of 'material object' is certainly controversial (and negotiable for the theist) (2009: 211).

I'll argue below that theists who are sympathetic to a non-reductive model of omnipresence in terms of ubiquitous entension have ample historical motivation to be open to

\footnotetext{
${ }^{14}$ Here I ignore the minor variations between the accounts offered by Hudson $(2009,2014)$ and Pruss (2013). One notable difference hinges on whether or not ubiquitous entension is compatible with divine timelessness. Hudson answers in the negative, Pruss in the affirmative. Pruss employs David Lewis' distinction between external and personal time, roughly the difference between objective time and inner time, respectively. To illustrate, consider the following remark by the backwards time-traveler: "In five minutes (internal time) I'll be in the Mesozoic era (external time)." Pruss defines omnipresence in terms of God's being wholly located at every place of space at every external time. He takes God's atemporality to be a matter of his being internally or personally atemporal, that is, God's inner life has no internal time.

${ }^{15}$ As Hudson endorses a substantivalist theory of spacetime, he glosses Occupation in terms of regions of spacetime as opposed to the more neutral 'place.'
} 
negotiate as to whether Occupation correctly demarcates the material from the immaterial.

But note here that the threat of divine materiality is in no way limited to one's endorsement of Occupation. Rather, an entension-based reading of omnipresence gives rise to the above untoward theological commitment on similar analyses of 'material object,' ones that have received much wider support in both historical and contemporary settings:

Extension: $x$ is a material object $=_{d f} x$ is spatially extended.

Location: $x$ is a material object $=_{d f} x$ has a spatial location.

An object is spatially extended, according to some, if it occupies or is located at a non point-sized region of space. ${ }^{16}$ According to Extension, materiality consists in being 'spread out' or distributed across space, and not merely occupying or being located at a region of space per se. It is standard to trace the roots of Extension to Hobbes and Descartes, though some have recently pointed out that Descartes was sympathetic with the notion that even immaterial entities can be extended in space in a particular sense. ${ }^{17}$

Some philosophers have argued that Extension ought to be rejected in so far as it rules out, a priori, the existence of point-sized material objects. If to be material is to be extended in space, then seemingly unextended objects - perhaps quarks, photons or other subatomic particles - are rendered immaterial on this view. And some might find it rather odd that, according to Extension, material objects like trees and bicycles are composed of a vast number of immaterial entities. Others are not as perturbed by the implication that subatomic particles turn out immaterial on Extension. In so far as one is inclined to think that an object's being extended in space suggests that it is composed of parts and perhaps has a spatial surface or boundary, one might follow van Inwagen (1990: 19) in thinking that, "talk about the surfaces of submicroscopic objects, or about the stuffs they are made of, tends to verge on nonsense."

By my lights, Location is the widely assumed yet rarely argued for analysis of 'material object' underlying debates in contemporary metaphysics and philosophy of mind. ${ }^{18}$ Ned Markosian (2000) is a notable exception here in that he has explicitly argued in favor of Location and has offered a number of reasons to prefer his view over rival accounts.

Not all are fond of Location, however. Hudson (2005: 2-3) rejects the view on the grounds that it misclassifies regions of substantival space as material. While Hudson

\footnotetext{
${ }^{16}$ See Carroll and Markosian (2010: 189-190).

${ }^{17}$ Pasnau (2011b: 334). See Descartes (1985), Letters to More V: 269.

${ }^{18}$ Two quick examples. Hoffman and Rosencrantz (2002: 40) claim as "unquestionably true" the following premise in what they call the classic argument against dualistic interactionism in the philosophy of mind: "Necessarily, a body, but not a soul, has spatial location" and "...we regard not being spatially located as a logically necessary condition of being a soul." Moreover, in addressing the rejoinder to his classic pairing problem for (interactionist) substance dualism that takes the soul to be spatially located, Kim (2005: 90) asks "why aren't souls just material objects, albeit of a very special and strange kind.'
} 
fails to elaborate on this point, his worry appears to turn on the fact that in contemporary philosophy of physics substantival spacetime, in particular the manifold $M$ of general relativity, is widely thought to be an immaterial or, at the very least, a dematerialized substratum that supports fields, geometrical and topological properties, as well as the structures that define absolute motion. ${ }^{19}$ Presumably, Hudson takes the 'is locatedat' relation to be reflexive such that every region of space is located at itself, which misconstrues regions of space as material on the view in question.

The point remains that if one follows Hudson and Pruss in explicating God's omnipresence in terms of ubiquitous entension, then God is both wholly located at (or 'occupies') the maximally inclusive non-point-sized place, and is wholly located at (or 'occupies') every proper subregion of that place, both of which render God a material object by the lights of Location, Occupation, and Extension.

Here I recommend that the orthodox theist not bite any bullets regarding the materiality of God in explicating omnipresence in particular as well as God's relationship to spacetime in general. Instead, I want to offer some friendly advice to those who are attracted to the ubiquitous entension model of omnipresence to explore alternative analyses of 'material object' than those currently on offer in the contemporary literature. I hope to show in what follows that the theist has solid historical precedent in the history of Christian philosophical theology for entertaining the view that immaterial beings in general can be spatially located at various non-point sized places in space, and thereby reexamine whether Occupation, Extension, and Location suffice to demarcate the material from the immaterial.

\section{Latin Medievals on the Location of the Immaterial}

In contrast to the contemporary metaphysical landscape that tends to assume an inseparable link between having a spatial location or extension and being material, some have recently pointed out, quite independent of recent work in contemporary metaphysics, that Latin medieval thinkers were in broad agreement that immaterial entities such as God and human souls were spatially located in some sense or other in their interactions with material beings. ${ }^{20}$

\footnotetext{
${ }^{19}$ See Wayne (2008). Earman (1989: 155) notes: “When relativity theory banished the ether, the spacetime manifold $\mathrm{M}$ began to function as a kind of dematerialized ether needed to support the fields. . . . [I]n post-relativity theory it seems that the electromagnetic field, and indeed all physical fields, must be construed as states of $\mathrm{M}$. In a modern, pure field- theoretic physics, M functions as the basic substance, that is, the basic object of predication."

${ }^{20}$ In addition, William of Ockham (1991) offers the following concise statement of the location of angels: "As for the second article, I claim that 'to be in a place' is taken in two ways [viz.,] circumscriptively and definitively. What is circumscriptively in a place is a thing which is such that (i) a part of it is in a part of the place and (ii) the whole of it is in the whole of the place. On the other hand, a thing is definitively in a place when (i) the whole of it is in the whole place and not outside the place and (ii) the whole of it is in each part of the place...I claim that an angel is not through his substance in a place in the first
} 
Consider the following remarks by Robert Pasnau (2011a:19) on medieval conceptions of divine omnipresence in particular:

Although it is now commonly supposed that God exists outside of space, this was not the standard conception among earlier theologians. Medieval Christian authors, despite being generally misread on this point, are in complete agreement that God is literally present, spatially, throughout the universe. One simply does not find anyone wanting to remove God from space, all the way through to the end of the seventeenth century. Of course, no one wanted to say that God has spatial, integral parts. So the universally accepted view was that God exists holenmerically throughout space, wholly existing at each place in the universe...God can be said to exist everywhere, and at every time, and to exist wholly wherever and whenever he exists.

In the place of 'entension' Pasnau adopts the more traditional terminology of 'holenmerism' to characterize the unique way the Latin medievals thought of God's presence to material creation.

My aim in this section is to offer a small sampling of the aforementioned Latin consensus regarding the truth of the conjunction of the following three theses:

Extended Location: God and human souls have non point-sized spatial locations. $^{21}$

Immateriality: God and human souls are immaterial.

Simplicity: God and human souls are mereologically simple. ${ }^{22}$

To the contemporary analytic philosopher the above three theses appear to be in deep tension with one another. We have already noted the tension between Extended Location and Immateriality. Common analyses of 'material object' on offer-Occupation, Location and Extension - preclude an immaterial object's being located at or extended in any place in space whatsoever. To be related to space in such a manner just is what

way. For an angel does not have parts and, consequently, is not circumscribed by a place...However, through his substance an angel is in a place in the second way, i.e. definitively. For his whole substance is in the whole of that place, and his whole substance is in each part of the place-not just in the sense that the angel's substance is present to the place (for God is present to the place in that sense), but also because the angel is in some way surrounded by and contained by the place, so that he is in that place and is not outside the place in which he is...And so just as the located body is in a place, so too an angel who is present to that body and to all its parts is in a place - though the body is in the place circumscriptively and the angel definitively." (Quod. I, q. 4, a. 3, emphasis mine).

${ }^{21}$ More specifically, subsequent to the the creation of the physical universe, God is located at various non point-sized places in space; and at least throughout its ante-mortem career, the human soul has a non pointsized spatial location.

${ }^{22}$ This, of course, is only one part of the doctrine of divine simplicity. Here I confine my discussion to the mereological implications of the doctrine and not those involving the denial of monadic and polyadic properties (both intrinsic and extrinsic) to God. 
it is to be material. Moreover, the conjunction of Extended Location and Simplicity is in tension with the principle, which arguably underlies much of the resistance to the possibility of extended material simples: that necessarily, if $x$ is entirely located at a non-point sized region $p$ and $p$ is mereologically complex, then $x$ is mereologically complex. If, as some are inclined to think, the mereological structure of an object must mirror the mereological structure of the place where it is located, then no simple object can be located at a non-simple place.

With the above tension noted, let's begin by turning to Extended Location, Immateriality, and Simplicity in the work of Augustine.

\subsection{Augustine}

Both early and later medieval discussion concerning the nature and location of immaterial entities was in large part shaped by the work of Augustine (354-430), particularly his discussion of the soul and the various relations in which it stands to the body.

Concerning the immateriality of the soul, Augustine remarks that "the soul is immaterial is a fact of which I avow myself to be fully persuaded" (Letter 166, 2.4). He does not, however, infer from the immateriality of the soul that it therefore lacks spatial location. As Goetz and Taliaferro (2011:43) point out, "Given that the soul isn't corporeal in nature, one would expect Augustine to maintain that the soul is not in space. Nevertheless, he affirms that the soul is in space, but not in the same way in which something corporeal is in space."

For Augustine, matter is located in space in such a way that "[e]ach mass that occupies space is not in its entirety in each of its single parts, but only in all taken together. Hence, one part is in one place; another part in another" (Immortality of the Soul, 16.25); elsewhere he makes the same point that matter is located in space by "every part of it [being] less than the whole" (Letter 166,4).

The soul, by contrast, is "in any body... whole in the whole and whole also in any part of the body" (On the Trinity 6.2.8). More specifically,

For [the soul] pervades the whole body which it animates, not by a local distribution of parts, but by a certain vital influence, being at the same moment present in its entirety in all parts of the body and not less in smaller parts and greater in larger parts, but here with more energy and there with less energy, it is in its entirety present in the whole body and in every part of it. (Letter 166, 2.4)

The capacity for a distinct type of spatial location is partly what sets the soul apart as immaterial for Augustine. In fact, he goes so far as to say that it would be impossible for the soul to be wholly located in every part of the body were it material. He notes:

Now, this presence of the mind in all parts of the body at the same moment would be impossible if it were distributed over these parts in the same way as we 
see matter distributed in space, occupying less space with a smaller portion of itself and a greater space with a greater portion. For all things composed of matter are larger in larger places or smaller in smaller places, and no one of them is in its entirety present as any part of itself, but the dimensions of material substances are according to the dimensions of the space occupied. (Letter 166, 2.4, emphasis mine)

When discussing the way in which the soul is located in the body in particular, Augustine is at pains to first distinguish the various ways in which the material and the immaterial are related to space in general. He states:

If matter be used to designate nothing but that which, whether at rest or in motion, has some length, breadth, and height, so that with a greater part of itself it occupies a greater part of space, and with a smaller part a smaller space, and is in every part of it less than the whole, then the soul is not material. (Letter 166, 4)

For Augustine, then, one of the marks of the material is being located in space in a particular kind of way, namely by being partly located at distinct places such that "every part of it [is] less than the whole." With respect to the mereological simplicity of the soul and its mode of spatial location with respect to the body, Augustine says, "When we come to a spiritual creature such as the soul, it is certainly found to be simple in comparison with the body...The reason it is simpler than the body is that it has no mass spread out in space, but in any body it is whole in the whole and whole also in any part of the body." (On the Trinity 6.2.8)

In sum, Augustine situates the distinct ways in which the soul and body are located in space within a more comprehensive view of the material-immaterial divide, one that is characterized at least in part by the capacity for distinct ways of being located in space. Like all material objects, the body is located at a place by being partly located at every part of that place; in the parlance of contemporary metaphysics, the body pertends in space. Being immaterial, the human soul is located at a place by being, "whole in the whole and whole also in any part of the body" (On the Trinity, 6.2.8); in contrast to material beings, the soul entends in space.

Turning now to Augustine's view of divine omnipresence, he famously records in his Confessions his adolescent struggle to conceive of the divine nature as being anything other than extended throughout space "as a great being with dimensions extending everywhere, throughout infinite space, permeating the whole mass of the world..." (1961:134). He writes, "I could not free myself from the thought that you were some kind of bodily substance extended in space, either permeating the world or diffused in infinity beyond it" (1961:133). He later goes on to acknowledge the error of his adolescent and Manichean ways by saying: "This was the theory to which I held, because I could imagine you in no other way. But it was a false theory."

Once again, one might think that Augustine's more developed and mature view of God's omnipresence was one that removed God from space entirely. As was the case 
with the soul above, this would be much too quick. In Letter 187 titled "On The Presence of God" where Augustine explicitly addresses the question of how God is everywhere present, he is, as with his remarks on the soul above, at pains to situate God's unique presence in the world within a larger framework concerning the material-immaterial divide:

And yet, when we say that God is everywhere, we must resist carnal thinking and withdraw the mind from the senses of the body so that we do not suppose that God is spread out through all things as if by spatial magnitude in the same way that the earth, or a liquid, or air, or this light is spread out. For every magnitude of this sort is smaller in a part than in its whole. (Letter $187,4.11)$

The divine nature, for Augustine, is not related to space as material objects are related, namely by having distinct parts that are extended or distributed across space. Along the same lines:

Yet he is not spread out in space like a mass such that in half of the body of the world there is half of him and half of him in the other half, being in that way whole in the whole. Rather, he is whole in the heavens alone and whole on the earth alone and whole in the heavens and in the earth, contained in no place, but whole everywhere in himself. (Ibid.)

Perhaps the clearest statement of Augustine's positive view of divine omnipresence is found in Letter 187 as follows:

On this account is He said to be everywhere, because He is absent to no part; on this account is He said to be whole, because He presents not one part of Himself to a part of things, and another part of Himself to another part of things, equal part to equal parts of things, a less to lesser parts, greater to a greater part; but He is equally present as a whole not only to the whole of the universe, but also to each part of it. (Letter 187, 17 emphasis mine)

In Sermon 277 Augustine vividly illustrates this view of omnipresence by comparing the way that human beings are located at a place-namely, by being wholly located at a single place at a particular time - with the way in which God is wholly located at every place at the same time:

You too, I mean, are the whole of you in your house and the whole of you here in church; but when you're in church you are not in your house; when you're in your house, you are not in church. So it's not the same with him...the whole of him is everywhere simultaneously. After all, he isn't poured out like water, or divided and carted around in bulk like earth. When he is all on earth, he doesn't abandon heaven; again, when he fills heaven, he doesn't withdraw from earth. (Sermon 277, 13) 
As before in the case of the soul and the body, the point of contrast here is between the distinct ways in which God and material objects are each located in space, not between lacking a spatial location and having a spatial location.

Augustine routinely characterizes God's ubiquitous presence not in terms of his being removed from space altogether but, rather, as a particular way of being located in the totality of space that preserves God's absolute mereological simplicity and thus in direct contrast to the mode of location exhibited by material beings. While the soul is exclusively located where the body is and is wholly located at each of the parts of the body, God alone is "equally present as a whole not only to the whole of the universe, but also to each part of it."

While it is equally true that Augustine adamantly rejects the notion that God is strictly speaking "in a place", it is important to be clear on what exactly he means by this locution. For an object to be "in a place," for Augustine, is for it to be "contained" in a place such that the object could not exist without being located at a place. Material objects are "contained" in a place in that their existence depends on their being somewhere. ${ }^{23}$ In his own words: "take from bodies their places and they will be nowhere, and because they will be nowhere they will not exist." By contrast, God "is not contained by those things to which he is present, as if he could not exist without them" (Letter 187, 6.18). ${ }^{24}$

Augustine seems to think that it is precisely because bodies are contained in space in this particular way (i.e. they must be in some place or other) that they are material:

Have no doubts at all about this: that God is not a body. It is proper to bodies to be spread out through space, to be contained in place, to have parts, halves, thirds, quarters, wholes. Nothing like that with God, because God is whole everywhere, not half of him in one place, with the other half somewhere else; but all of him is in heaven, all of him on earth. (Sermon 277, emphasis mine)

Again, for Augustine the contrast here is between (a) material objects that are (i) mereologically complex, (ii) wholly located at a single place (i.e. not strongly multi-located), (iii) cannot exist without being located at some place or other, and (iv) are partly located at distinct places; and (b) God as an immaterial entity that (i) is mereologically simple, (ii) is wholly located at every place, (iii) can exist without being located at a place (say,

\footnotetext{
${ }^{23}$ Where the notion of dependence here, I take it, is most charitably read as generic dependence. While the existence of a material object necessitates the existence of some place or other, it need not necessitate the existence of the place it presently occupies (or else it couldn't change location without thereby ceasing to exist).

${ }^{24}$ See further Letter 277: “Only don't let us strive to reduce God to a place, don't let us strive to shut God up in a place, don't let us strive to spread God out in any kind of bulk through extended space; let us not have the nerve to do that, let's not even think of it. Let the substance of divinity remain in its own proper dignity. Let us, certainly, as far as we can, change for the better; let us not change God for the worse." Again, the primary issue for Augustine here is not being located in space per se but to safeguard God's ontological independence from space as well as the absolute simplicity of the divine nature.
} 
prior to creation), and (iv) is partly located at no place. Consequently, the reason why God is not "in a place" on Augustine's use of the phrase is that God (unlike material objects) is neither confined to a single place nor metaphysically dependent on space for his existence.

Consequently, Augustine appears to be committed to the conjunction of Extended Location, Immateriality, and Simplicity. Immaterial objects such as God and the human soul can be wholly located at a non-point sized place (for God: the maximally inclusive place where the universe is entirely located; for the human soul: the place where the body is entirely located), and wholly located at each part of that place (for God: each subplace of the maximally inclusive place where the universe is entirely located; for the human soul: each subplace of the place where the body is entirely located).

\subsection{Anselm}

Let us turn now to Saint Anselm of Canterbury (1033-1109), the premier philosophertheologian of the eleventh century. With his usual precision and clarity, Anselm devotes chapters 20-24 of his Monologion to a systematic discussion of God's unique relationship to place and time. He constructs a disjunctive syllogism whose major premise consists of the following three disjuncts. God is either:

(i) "everywhere and always (i.e. in every place and time)."

(ii) "only somewhere and sometime (i.e. limited to some place and some time)", or

(iii) "nowhere and never (i.e. in no place or time)" (1998: 33-34).

Anselm quickly dismisses options (ii) and (iii) based on considerations of God's absolute simplicity as well as God's universally sustaining creatures in existence. Starting with (iii), Anselm rejects the notion that God exists "nowhere and never (i.e. in no place or time)" on the grounds that absolutely nothing exists without God's immediate sustaining causal activity (cf. Monologion 13), conjoined with the more general principle that "Absolutely no essence exists where and when he does not exist, since without him nothing exists" (2007: 28). As Brian Leftow (1991: 187) has pointed out, here Anselm relies on the more general tenet that an immediate cause is present to or located where its effect is located, where and when the effect exists/occurs (assuming, of course, that the effect has a location in space and time). ${ }^{25}$ Anselm goes so far as to say, "...since nothing at all exists without him, if he exists nowhere and never, then every good thing exists nowhere and never, and absolutely everything exists nowhere and never. Just how false that is, there is no need to say" (2007: 28).

In rejecting (ii), the thesis that God is "only somewhere and sometime (i.e. limited to some place and some time)", Anselm relies once again on God's direct sustaining of

\footnotetext{
${ }^{25}$ See Leftow (1991: 187).
} 
material beings, yet in such a way that does not assume the principle that an immediate cause must be where its effect is located. According to Anselm, God is absolutely simple and thereby devoid of distinct parts and properties. Being absolutely simple, God is identical to his causal activity or power. And since God's sustaining power extends to every place, upholding all things in existence, it therefore follows from divine simplicity that God cannot be present only somewhere and sometime but must himself be present in his entirety to every place and time.

In fact, Anselm emphatically rejects the notion that God is capable of being located at every place and time solely in virtue of his immediate causal power, while himself being (non-causally) located at a single place and time. In his own words, "And if it is said that through himself he exists determinately at a certain time and place, but through his power he exists wherever and whenever anything exists, that is not true. For since it is evident that his power is nothing other than himself, his power in no way exists apart from him" (2007: 28). Consequently, Anselm highlights two lines of reasoning in favor of the view that God is "everywhere and always (i.e. in every place and time)" as stated in (i), namely God's immediate sustaining activity in creation and God's absolute simplicity.

In chapter 21, Anselm argues that God must be "everywhere and always (in every place and time)" in one of two ways, either:

(a) existing "as a whole only in the sum of all places and times, and existing in its parts in each individual place and time," or

(b) existing "as a whole in the sum of all places and times and existing as a whole in each individual place and time." (1998: 34-35, my emphasis)

Note first the striking similarity between Anselm's (a) and (b) and the aforementioned relations of pertension and entension, respectively. Anselm rejects (a) outright on the grounds of God's absolute mereological simplicity: what lacks parts entirely cannot be partly located in any sense. This leaves (b). The nub of Anselm's objection to (b) turns on the seeming impossibility of an entity's being wholly located at more than one place at the same time: he says, "One whole, therefore, cannot be simultaneously in several places as a whole" (35). If such a strong form of multi-location is impossible, it follows that contrary to (b), "There is no way for the supreme essence to exist as a whole in every place and time."

Anselm thus faces paradox: God is both located at every place and time (conclusion of chapter 20) and located at no place and time (the conclusion of chapter 21). At this point Hudson (2009: 201), following Wierenga (1997), claims that Anselm resolves the paradox in chapter 22 by positing two mutually exclusive location relations which correspond to the way in which material and immaterial objects are located at a place. As Wierenga puts it: "Anselm then attempted to reconcile this 'contradictory languagebut ineluctable logic' by distinguishing between two senses of 'being wholly in a place,' 
namely, being contained in a place and being present in a place" (258). Since being literally located at a place in the way that material objects are located amounts to being 'contained in' that place, God is literally nowhere on this reading of Anselm. Yet God can be said to be located at each place in a non-literal sense in virtue of being 'present at' every place, where being present to every material creature in this way need not compromise the absolute simplicity nor the transcendence of God. Paradox is avoided in chapter 22, then, precisely because the sense in which God is present at every place and time is distinct from the sense in which he is contained in no place and time.

I believe this reading of Anselm's resolution to the paradox in chapter 22 is mistaken. I'm inclined to think instead that Anselm's way out of the paradox turns, at bottom, on his general views concerning the material-immaterial divide. At the start of chapter 22 of Monologion, Anselm returns to (b) and asks, "perhaps [God] can exist as a whole in individual places and times." His reason for reconsidering (b) as a minimal condition on omnipresence hinges on a wider, overarching view as to what it means for an entity to be material, that is, an entity confined to or "bound by the law of place and time" (1998: 39).

Anselm identifies two principles that govern what he calls "temporal and spatial natures," which are "under the rules and regulations of time and place:"

This, then, is what time and space stipulate: that (and only that) which is enclosed in their limits, neither escapes the logic of (spatial and temporal) parts and wholes, nor exists as a whole in more than one place and time simultaneously. (1998: 38)

It seems that for Anselm, then, an object $x$ is material just in case (i) $x$ is composite, and (ii) $x$ is incapable of being wholly multiply located at one and the same time. In true Augustinian fashion (cf. Letter 166, 2.4 above), Anselm holds that it is strictly impossible for material objects in particular to be wholly multi-located, that is, wholly located at distinct places at the same time. By contrast, for God qua immaterial being, "the long arm of space and time does not encircle: [and] is neither condemned to the multiplicity of having parts, nor prohibited from being present as a whole in more than one place and time simultaneously" (1998: 38).

On this reading of Anselm, the solution to the above paradox resides primarily in the immaterial nature of the supreme substance. Being immaterial, God is not localized or confined to a particular place like material objects, and hence can exhibit the strong form of multi-location required by (b) above. Being absolutely unlimited, God is capable of being wholly located at every place whatsoever without being 'bound to' or 'contained in' a single part of space or the whole of space in its entirety.

In chapter 22 of the Monologion, Anselm is unequivocal that while God and material objects are both related to place in some sense, only the latter are 'contained' in the places where they are located (1998: 39); God in no way depends on place for His existence. In a way that bears a striking resemblance to Augustine's own remarks above, Anselm reasons that for an object "which does not commit its existence to a place and 
time is neither forbidden nor obliged, by the law of space and time, to be, or not to be, in some place and time" (1998: 39). Though God is wholly located or present at every place and time by his own volition, his existence in no way depends on being related to place and time as such.

Anselm concludes the above discussion with the following remarks in support (b) as a necessary condition on God's omnipresence:

Since, as I say, this is what time and space stipulate, I do not doubt that the supreme substance is exempt. No time or place, after all, contains it. Now, ineluctable necessity demands that the supreme essence be absent from no place or time. And, further, no space and time legality prohibits it from being present at every place and time simultaneously. I conclude, therefore, that it is necessary that it be present as a whole simultaneously to all places and times, and to each individual place and time. (1998:38, my emphasis)

While Anselm's full account of divine presence in the world no doubt includes more than what is captured in (b) above - namely, God's being directly cognitively aware of and sustaining in existence every material creature - there are good interpretive grounds for thinking that it is certainly nothing less than God's being wholly spatially located in the whole of space, and wholly spatially located in each part of space as well. With Brian Leftow (1989: 354) we can affirm that, for Anselm, God "is literally in space, but not as a material thing is." 26

It is interesting to note that in Proslogion 13 Anselm makes a similar appeal to the material-immaterial divide concerning the mode of location of the body and the soul, contrasting the two precisely in terms of their ability or inability to be wholly located at more than one place at the same time. Anselm remarks:

Certainly that is absolutely limited which, when it is wholly in one place, cannot at the same time be somewhere else. This is seen in the case of bodies alone...That, however, is limited and unlimited at the same time which, while wholly in one place, can at the same time be wholly somewhere else but not everywhere; and this is true of created spirits. For if the soul were not wholly in each of the parts of its body it would not sense wholly in each of them. (1998: 95) ${ }^{27}$

\footnotetext{
${ }^{26}$ For an interesting discussion concerning Anselm's fully developed account of omnipresence see the dialogue between Wierenga (1988) and Leftow (1989). Also, see Pasnau (2011a) for an interpretation of Anselm's view of divine eternity that coheres with the interpretation of Anselm's view of omnipresence offered here.

${ }^{27}$ Note here the explanatory ordering: the soul's being wholly located at every part of the body explains its ability to sense at each part of the body, and not vice versa. This suggests that the notion of "being located at" or "present to" some place is distinct from an object's have immediate knowledge or sensation at that place. This further suggests, contrary to Hudson and Wierenga, that Anselm does not consider the deepest account of God's omnipresence to be captured in terms of God's immediate sensation or knowledge of the goings on at every point in space.
} 
Again, there is no suggestion here that material objects (bodies) have a spatial location and immaterial objects (created spirits) lack a spatial location, and that each bear distinct location relations to place in general. Rather Anselm contrasts the two kinds of objects in terms of the possibility or impossibility of being wholly multi-located. As noted above, for Anselm, the inability of a body to be wholly multi-located at distinct places is constitutive of its materiality, while the ability of the human soul to be wholly multi-located at each place in the body is constitutive of its immateriality.

As was the case with Augustine above, Anselm's view of omnipresence and the location of the soul in the body commits him to the conjunction of Extended Location, Immateriality, and Simplicity. In neither of these Latin medieval thinkers do we find an account of the interaction between the immaterial and the material domain that is explicated in non-spatial terms. Rather, in sharp contrast to the way in which material beings are located in space, both God and human souls are located in space in such a way that preserves both their mereological simplicity as well as their ability to be wholly located at distinct places at the same time.

In claiming that Anselm endorses the conjunction of Extended Location, Immateriality, and Simplicity regarding the divine nature in particular, I take issue with the interpretation of his account of omnipresence offered by Hudson $(2009,2014)$ and Wierenga (1997). Hudson claims that both Anselm and Aquinas "develop accounts of omnipresence and its characteristic 'being present at' relation that are parasitic on our understanding of the straightforward, non-mysterious occupation relation with which we are all familiar" (202). For Anselm in particular, Hudson and Wierenga claim that God is not located at every place in a literal, spatial sense but, rather, is located at every place only in the sense of having direct cognitive awareness of every material object that is itself located in a literal, spatial sense. In short, Hudson and Wierenga construe Anselm as a proponent of what I am calling a DO model of omnipresence.

As was noted above, I think the overarching location relation employed by Anselm in his account of God's relationship to space in Monologion 20-22 is the straightforward, ordinary variety of spatial location. Where God and material objects differ in their relationship to space pertains to the distinct ways in which they are spatially located, namely by either entending or pertending the places where they are entirely located. While Anselm relies heavily on the relations of entension and pertension (or something very similar) as distinct modes of spatial location exhibited by immaterial and material entities respectively, I take him to be working with a single, basic location relation - namely 'present at' - in which entension and pertension are characterized in terms of.

In contemporary parlance, my claim here is that Anselm endorsed something along the lines of what we might call locational monism, the view that there is a single, basic (i.e. irreducible) location relation that relates objects to places. ${ }^{28}$ And for Anselm the basic

\footnotetext{
${ }^{28}$ One can adopt a monistic or pluralistic stance with respect to a number of relations, whether parthood, causation, identity, etc. As far as I am aware, the terms were first introduced by McDaniel (2004) in the context of compositional monism and compositional pluralism. See also his (2009).
} 
location relation that ties material and immaterial objects to space is the 'present at' relation. Entities that stand in the 'present at' relation to some place are, quite literally, spatially located at that place, irrespective of whether they are material or immaterial. Of course locational monism is consistent with there being multiple, non-basic location relations that are defined in terms of the single basic notion; and on the reading of Anselm I am offering here, the non-basic location relations of entension and pertension are defined terms of the single basic 'present at' relation.

While Hudson and Wierenga also attribute to Anselm a version of what I am calling locational monism, they nevertheless offer the relation of containment as the basic relation at work in Anselm's account. On their reading of Anselm, he defines the derivative 'present at' relation in terms of bearing a relation to an object that is itself 'contained in' a place. On this view, only material objects stand in the basic containment relation to places and, as a result, are the only objects that can be properly said to have a spatial location; God and other immaterial beings, by contrast, exclusively stand in the nonbasic 'present at' relation to their respective places, and thus fail to be located in space in the above straightforward or literal sense.

I'll conclude this section by offering one final consideration in favor of interpreting Anselm along the lines of a locational monism that takes the 'present at' relation as the single basic relation that ties both material and immaterial objects to places.

In Monologion 22 Anselm makes the point that material objects are both 'present at' times and places as well as 'contained by' times and places. In addressing the sense in which both God and material objects, i.e. "localized or temporal natures," are 'present at' times and places, Anselm remarks:

For if that supreme essence is said to exist in a place or a time, even though the very same expression is used both of him and of localized or temporal natures because of our customary way of speaking, there is a different meaning because of the dissimilarity of the things themselves. When it comes to localized or temporal natures, this one expression signifies two things: that they are present at the times and places in which they are said to exist, and that they are contained by those times and places. But in the case of the supreme essence, only one of these meanings applies, namely, that he is present, not that he is contained by them. (2007: 33, emphasis in original)

If Anselm was of the opinion that being 'present at' and 'contained in' a place denoted two mutually exclusive relations as claimed by Hudson and Wierenga - which they would need to be to avoid the contradiction addressed in ch. 22 of Monologion - then it is puzzling that Anselm would affirm that material objects stand in both relations to places and times. Far from thinking that the 'present at' relation exclusively relates immaterial beings to space, Anselm is unequivocal that both God and material objects are 'present at' the places where they are located; this alone ought to call into question the above reading of Anselm proposed by Hudson and Wierenga. 
It seems more likely that God's failing to be 'contained by' place amounts to the claim that God, in contrast to material beings, is neither metaphysically dependent on place nor delimited by the dimensions of the places where God is located. We need not interpret Anselm as taking the notion of containment as a distinct, mutually exclusive location relation in contrast to the 'present at' relation. God is not contained by any place only in the sense that his nature in no way constrains his ability to be wholly multilocated at distinct places at the same time, or to be located at no place at all.

Consequently, what is doing the heavy-lifting in Anselm's account of omnipresence is, at bottom, the notion that God is wholly located at the sum of all places in space, and wholly located at each individual place in space, i.e. (b) above. In contemporary parlance, Anselm is of the view that God's omnipresence amounts to God's entending the totality of space, where the location relation at work in ubiquitous divine entension is the same basic relation that relates material objects to places. ${ }^{29}$ While it is certainly true that Anselm is of the opinion that God stands in immediate causal and cognitive relations with material beings (see Monologion 13 \& 14), it is another thing entirely to hold that Anselm thought that God's standing in these relations is constitutive of divine omnipresence per se.

In his recent book tracing the history of late medieval and early modern metaphysics, Robert Pasnau (2011b: 337) makes the following statement: "Holenmerism [what I am calling 'entension'] is the standard view regarding immaterial entities God, angels, and rational souls - from Plotinus, Augustine, and Anselm all the way through the scholastic era. Nearly all the leading scholastic authors embrace this position, including Bonaventure, Aquinas, Scotus, Ockham, and Buridan." Likewise, medieval historian and philosopher of science Edward Grant (1981: 355, n.33) makes the same general point that what I am calling 'entension' was:

[T] he fundamental medieval concept that God is wholly in the whole of a space and wholly in every part of that space, a concept that was also applied to other spiritual substances, such as souls and angels. It was the common medieval manner of explaining how a spiritual substance could occupy a body or place and yet remain indivisible despite the divisibility of the body or place.

My aim in this section has been to substantiate, at least to some degree, the above claims of Pasnau and Grant regarding Extended Location, Immateriality, and Simplicity in Augustine and Anselm in particular.

\footnotetext{
${ }^{29}$ As a result, I'm inclined to think that Anselm's own view of omnipresence is the same as or highly similar to the one defended by Hudson $(2009,2014)$ and Pruss $(2013)$, namely ubiquitous entension.
} 


\section{The Material-Immaterial Divide Revisited}

On the overarching theistic metaphysic endorsed by Augustine and Anselm, an entity's being located at an extended or non-point sized place per se is not sufficient to mark it out as material. As was noted above, this sets them in contrast to widely endorsed analyses of the nature of the material in the contemporary literature. ${ }^{30}$

But suppose the theist is attracted to the above line of thinking that allows for immaterial objects to entend the non-point sized places where they are spatially located. How might the theist resist the unorthodox view that God is a material object, given that standard analyses of 'material object' preclude God's being situated in space in this manner? What alternative account might the theist offer in the place of Occupation, Location, and Extension? I conclude by exploring several alternative analyses of 'material object' that are broadly inspired by the views of Augustine and Anselm above.

In what follows I aim to satisfy what I consider to be historically entrenched theological desiderata concerning the material-immaterial divide. At the very least, I consider the theological desiderata for an analysis of 'material object' to rightly classify paradigmatic instances of immaterial beings in the Christian tradition, namely, God, angels, and human souls. ${ }^{31}$ In so doing I aim to carve out space for the relation of entension and its application to immaterial beings as a viable, orthodox option in contemporary Christian philosophical theology. ${ }^{32}$

As a first pass, we might consider modally strengthening Location above to the following:

Modal Location: $x$ is a material object $=_{d f}$ it is part of the nature of $x$ to have a spatial location. ${ }^{33}$

\footnotetext{
${ }^{30}$ Though there are dissenters. William Lycan (2009), for instance, suggests that dualists opt for the view that minds are literally located in space (partly to solve the interaction problem); this would, by his lights, in no way undermine the mind's being immaterial. He then asks, "It may be wondered wherein minds are immaterial, if they are spatially located?", he then proceeds to answer, "In at least two ways: they do not have other physical properties such as mass or charge; and unlike brain matter, they are not made of atoms or subatomic particles." (558-559).

${ }^{31}$ As to the epistemic grounds for thinking that angels and human souls exist and are immaterial is beyond the scope of my concern here.

${ }^{32}$ The application of the relation of entension to Christian doctrine in particular is far-reaching, even if not employed in an analysis of divine omnipresence. Here I'm thinking of the application of entension to the incarnation, Eucharistic presence, and the indwelling of the Holy Spirit.

${ }^{33}$ Here one could modalize Occupation in the same sense, although I limit my discussion here to Location. Swinburne (1994: 9) offers a modal view of 'material object' that is in the same general neighborhood as Modal Location, although he is silent as to the various relations an object might stand in to regions of space. He states, "Those substances whose essential properties are such that they must occupy space (i.e. be spatially extended) I shall call material objects. The substance that is my desk could not be a desk unless it occupied space...If there is a substance which does occupy space but need not, it does not count as a material object on my definition" (9).
} 
On Modal Location, it is metaphysically impossible for material objects to exist without having a spatial location. Modal Location allows for immaterial entities to be spatially located, on the assumption that it is no part of their nature to be located as such.

But here those attracted to an account of the nature of human persons that involves an essential relation of some kind between body and soul - whether composite, emergent, or hylomorphic varieties of dualism - will register their discontent with Modal Location. On a hylomorphic conception of human persons, for example, the immaterial human soul, as the constituent that makes the organic body a human body in particular, is essentially such that it is integrally united to matter and thus spatially located at some time or other, even though the soul may be capable of existing disembodied in the intermediate state. ${ }^{34}$ The same would apply to any account of human persons that takes an immaterial soul or self to be, by nature, generated in some sense from the material domain, perhaps the brain in particular. If so, then Modal Location will be too rigid for certain views regarding the nature and composition of human persons.

Moreover, Modal Location lacks the resources to accommodate the traditional theological tenet that Christ ascended with, and presently has a physical human body, on the admittedly speculative assumption that Christ's resurrected body is no longer spatiotemporally located.$^{35}$ It is a consequence of Modal Location, together with this speculative assumption, that the resurrected body of Christ is no longer a physical human body. ${ }^{36}$

Yet another potential worry is that on certain historically prominent FO models of omnipresence in the Christian tradition, Modal Location entails that God is a material object in so far as there are no possible worlds in which God exists without being spatially located on these models. ${ }^{37}$ Recall from $\$ 1$ that FO models of omnipresence are those that hold that God is located at or present to each place fundamentally, i.e. in his own right, and not in virtue of standing in some relation to entities that are themselves present in the fundamental sense.

Yet according to the FO models of omnipresence espoused by the likes of Henry More, Isaac Newton, and more recently Robert Oakes, it is metaphysically impossible that God not be related to space in some sense or other. For More, it is part of the nature of God to be related to space in so far as he is identical to space itself; for Newton, though God is not identical to space, it is necessarily the case that God's existence necessitates the existence of absolute space: every world in which God exists is a world in which

\footnotetext{
${ }^{34}$ See Aquinas (1975) 4.79.10, "The [human] soul is, by nature, united to a body. For it belongs to its essence to be the form of a body. It is, therefore, contrary to the nature of the soul to be absent from the body."

${ }^{35}$ For historical reference to this theological idea, see Crisp (2007: 133, n. 28) where he cites The Heidelberg Catechism in Schaff (1877: 322-335) and The Formula of Concord, art. 7, pp. 568-591 in Tappert (1959).

${ }^{36}$ But see Hudson (2005: 204), Swinburne (1994: 235-237), and Van Den Brom (1993: 309 ff) for an interesting denial of this speculative assumption, one that tentatively appeals to Christ's body being spatially located or present in a higher-dimensional space.

${ }^{37}$ Thanks to R.T. Mullins for this point.
} 
he is everywhere present throughout absolute space; for Oaks, it is part of the nature of God to be related to space in so far as God is "maximally immanent in space-and, indeed, necessarily so: [since] space is an essential aspect of God."

Among the above FO model's of omnipresence, it appears that all but Newton's entail that God is a material object on Modal Location. For it is open to the contemporary proponent of the Newtonian model of omnipresence to argue, following a move made by Fine (1994) in the area of modal metaphysics, that essence is not reducible to modality; that something's being $F$, say being spatially located, in every possible world in which it exists is not equivalent to saying that being $F$ is part of its nature or essence.

The existence of Socrates modally necessitates the existence of his singleton set \{Socrates\}, yet it is arguably not the case that being a member \{Socrates\} is part of the essence of Socrates. In the same way, the defender of the neo-Newtonian account of omnipresence might argue that while God's existing in every possible world modally necessitates the existence of absolute space in every possible world, it does not follow that God is essentially related to space. Hence, adopting a more fine-grained, non-modal account of essence can allow the defender of a neo-Newtonian account of omnipresence to endorse Modal Location while sidestepping the worry that God is a material object.

For an alternative analysis of 'material object', one might consider following the general spirit of Augustine and Anselm's above remarks: to be 'material' is not to be essentially located in space per se, but to be essentially located in space in a particular kind of way, namely, by being partly located at distinct places via pertension.

Let's call this view Modal Pertension and define it as follows:

Modal Pertension: $x$ is a material object ${ }_{d f}$ it is part of the nature of $x$ to be located in space via pertension.

Modal Pertension rightly construes God and angelic beings as being immaterial in so far as they are, at least by the lights of most theists, in no way essentially related to space; God and angels are essentially immaterial and contingently related to space and its occupants. The human soul also counts as immaterial on Modal Pertension in that while it may (on some views) be essentially located in space at some time or other, it entends rather than pertends when it is, in fact, spatially located. When the above immaterial entities are located at various places in space, they are wholly located at those places as well as wholly located at every subplace of the places in question.

Modal Pertension does, however, preclude material objects from entending in space. This may seem much too strong for both theological and non-theological reasons alike. As pointed out by Marilyn Adams (2006), the likes of Aquinas, Scotus, and Ockham thought that in the Eucharist the physical body of Christ is literally wholly located at every place where the Eucharistic elements are located. ${ }^{38}$ Concerning thirteenth and fourteenth century Eucharistic theology in particular, Adams notes:

\footnotetext{
${ }^{38}$ For a contemporary defense see Pruss (2013).
} 
These positions shared the philosophically innovative thesis that bodies (like angels and souls) can be literally located in a place without being extended in it...Taking their cue from Augustine, scholastic philosophers reasoned that angels and intellectual souls cannot be extended in a place because they are simple and so lack parts that could be positioned at a distance from one another. But a human being's intellectual soul is located in his/her body throughout his/her ante-mortem career. Hence, the intellectual soul must be whole in the whole body, and whole in each part of the body (which Scotus and Ockham call being definitively in place). By contrast, material things do have parts, and their natural way of existing is to be extended in place, with some parts at a distance from others. Confronted with the problem of eucharistic presence...Aquinas, Scotus, and Ockham all reasoned that just because material things have parts and so can be and normally are in a place by being extended in it, it doesn't follow that it is metaphysically impossible for material things to be located in a place without being extended in it. Why would it be impossible for Divine power to make a material thing to exist in place definitively, so that the whole thing was in the whole of the place, and the whole thing was in each part of the place as well? (2006: 299-300) $)^{39}$

Hence one might argue that while material objects are disposed to pertend in space, it is much too strong to say that their nature demands that they must be located in such a way at each moment of their existence. ${ }^{40}$ While perhaps nothing other than divine power can make it the case that a material object be located in space via entension, one might suppose that such a state of affairs is at least metaphysically possible.

In addition to the above theological consideration, if one is a friend of the possibility of extended material simples in particular, then Modal Pertension appears to be ruled out in so far as such objects are commonly thought to entend rather than pertend the places where they are located. ${ }^{41}$

It's not clear to me whether the defender of Modal Pertension should be moved by this worry. For one, many philosophers are inclined to think that extended material simples are metaphysically impossible, partly on the grounds that the natures or properties of extended material objects in particular (e.g. their being identical to spacetime

\footnotetext{
${ }^{39}$ A succinct statement of this view is given by Ockham (1991): "On the other hand, a thing is definitively in a place when (i) the whole of it is in the whole place and not outside the place and (ii) the whole of it is in each part of the place - in the way that the body of Christ is definitively in a place in the Eucharist. For the whole of his body exists together with the whole of the place of the consecrated species, and the whole of his body exists together with each part of that place. (Quod. I, q. 4, a. 2).

${ }^{40}$ For a brief but helpful discussion of the various location relations employed by the medievals concerning the metaphysics of the Eucharist, see Adams (2006: 299-300). For an exhaustive treatment on these matters see Adams (2010), especially part two.

${ }^{41}$ For a discussion of the possibility of extended material simples see Parsons (2000), McDaniel (2007), and Simons (2004).
} 
regions, i.e. supersubstantivalism, or their exemplifying geometrical and topological properties) arguably preclude their being mereologically simple. ${ }^{42}$ If one has independent grounds for thinking that extended material simples in particular are metaphysically impossible, then the worry that Modal Pertension precludes the possibility of such material objects loses its force. Further, one might be hesitant to lay the bulk of the argument against Modal Pertension on the metaphysical possibility of extended material simples. The debate over whether or not such exotic material objects are possible is a relatively recent one in contemporary metaphysics and one that even the most speculative of metaphysicians is inclined to approach rather tentatively.

Even so, the defender of Modal Pertension who is a friend of the possibility of extended material simples has a straightforward reply: deny that entension is the only way for such exotic material objects to be located in space. Hudson (2005: 101), for instance, has suggested that extended material simples might also span their respective places, where he defines spanning as follows:

$x$ spans $p=_{d f} x$ is an object that is wholly and entirely located at exactly one non-point-sized place, $p$, and there is no proper subplace of $p, p^{*}$, such that any part of $x$ is located at $p^{*}$.

If an extended material simple spans some non point-sized place $p$, it fails to be wholly located at every subplace of $p$ (as it would if it entended $p$ ). The relevant difference between objects that span and objects that entend in space is that the latter are wholly multi-located at every subplace where they are located, while the former are not. ${ }^{43}$ Modal Pertension would, of course, need to be revised so as to include either pertension or spanning as the modes of location uniquely definitive of material objects. As long as it is open for extended material simples to span instead of entend their respective places, Modal Pertension so revised need not preclude the possibility of material objects of this kind.

If one is persuaded by the above theological and non-theological considerations against Modal Pertension, we might finally consider revising Modal Pertension to the following:

Dispositional Pertension: $x$ is a material object $=_{d f}$ it is part of the nature of $x$ to be disposed to be located in space via pertension.

As is well known, dispositions or powers can exist unmanifested; the manifestation of a power is liable to preventers, masks, finks, etc., such that an object's having the power

\footnotetext{
${ }^{42}$ See Hudson (2005), especially chapter 4, for a host of objections to the possibility of extended simples. Also, see Gilmore (2014) for a nice general summary of the current state of the debate.

${ }^{43}$ One potential problem with requiring extended material simples to span their respective places in the above sense is that it would seem to exclude the possibility of time-traveling scenarios involving enduring extended material simples. Such entities would be wholly multi-located at distinct places at the same time and thereby fail to span any one place in particular (though they would not entend those places in so far as they would fail to be wholly located at each of the proper subplaces of the places where they are located).
} 
in question does not necessitate the power's manifestation. ${ }^{44}$ The glass may be fragile without currently manifesting its disposition to break. In the same way, one might say that material objects are disposed by nature to either pertend (or span) the places where they are located, but nevertheless fail to manifest this disposition and instead entend their respective places.

As with Modal Pertension, Dispositional Pertension rightly construes God and angels as immaterial. Moreover, Dispositional Pertension can uphold the above theological account of Christ's real presence in the Eucharist: that Christ's body entends each place where the Eucharistic elements are located. The proponent of Dispositional Pertension might argue that while material bodies are disposed by nature to either pertend or span in space, the unique presence of Christ's body in the Eucharistic elements is secured directly by divine power; perhaps the special activity of God serves to both mask or prevent the manifestation of the powers that are part of the nature of Christ's body, as well as supply the additional power to entend each place where the elements are located.

Furthermore, Dispositional Pertension is also commendable on the grounds that it can accommodate a wide-range of views concerning the nature and composition of human persons, particularly those that claim that the immaterial soul is, in some sense or other, essentially related to the body. While one might think that the human soul is naturally disposed to be located in space at some time or other (which perhaps explains why disembodiment is a radically unnatural state), the soul fails to be material on Dispositional Pertension precisely because it has a disposition to entend rather than to pertend or span.

Dispositional Pertension is also well-positioned to maintain the traditional theological tenet that Christ presently has a physical human body, even though, as was hinted at above, Christ may fail to currently have a spatiotemporal location. Since bodies qua material objects in general (and Christ's body in particular) are by nature merely disposed to be located in space, their failure to manifest this disposition in no way entails that they lack this disposition and are thereby no longer material.

Finally, one might think that a theist-friendly account of the material-immaterial divide ought to be able to say something about why materiality is limiting, and thus why an unlimited or perfect being is necessarily immaterial. ${ }^{45}$ Call this the limiting constraint for materiality. ${ }^{46}$

Modal Location, Modal Pertension and Dispositional Pertension each go some way towards satisfying the limiting constraint. ${ }^{47}$ On Modal Location, since it is part of

\footnotetext{
${ }^{44}$ See Molnar (2003).

${ }^{45}$ Thanks to Alex Pruss for this suggestion.

${ }^{46}$ The limiting constraint for materiality raises obvious complications for physicalist accounts of the incarnation which maintain that God the Son was transformed into a material object, a living human body.

${ }^{47}$ It needs to be pointed out here that there have been a variety of different ways of satisfying the limiting constraint for materiality in the Christian tradition. Perhaps the most prominent historical grounds
} 
the nature of material objects that they have a spatial location (if they exist), it would appear that they metaphysically depend on space for their nature and existence. Since it is part of the nature of a perfect being that it exist $a$ se and thus metaphysically ungrounded, a perfect being must be immaterial on Modal Location. A similar line of reasoning can be applied to both Modal Pertension and Dispositional Pertension in so far as materiality is defined in terms of being essentially related to space in a particular manner.

But note that Modal Pertension and Dispositional Pertension have additional resources to ground the limiting constraint for materiality. Here I turn once again to Anselm's remarks in Proslogion 13 where he characterizes that which is 'absolutely limited" as that "when it is wholly in one place, cannot at the same time be somewhere else" (1998: 95). As I highlighted above, only material objects are absolutely limited in this sense for Anselm. By contrast, "That, however, is limited and unlimited at the same time which, while wholly in one place, can at the same time be wholly somewhere else but not everywhere; and this is true of created spirits" (1998: 95). Created immaterial beings, for Anselm, are 'unlimited' in that they are capable of being wholly multilocated at distinct places at one and the same time (they are 'limited' only in the sense that they are not located everywhere, as is God).

Following Anselm, then, we might say that an object's inability to be wholly multilocated is a genuine limitation, perhaps due to the fact that the scope of the object's immediate causal activity is necessarily restricted to a single place at any given time. Such a restriction is, of course, unfitting for an unlimited or perfect being. Since Modal Pertension and Dispositional Pertension construe materiality both in terms of essential dependence on space as well as location relations that are limiting in the above sense, they are doubly-suited to ground the limiting constraint for materiality.

Whether the orthodox theist opts for Modal Location, Modal Pertension, or Dispositional Pertension will, of course, depend on one's wider theological and philosophical commitments. The point remains that each furnish the theist with an account of the material-immaterial divide that allows for immaterial objects to entend the non-pointsized places where they are located, and thus be spatially located in a strict and literal sense. $^{48}$

for thinking that materiality is limiting, and thus why an unlimited being is necessarily immaterial, turns on an Aristotelian characterization of matter in terms of potentiality. For Thomas Aquinas and medieval Aristotelians in general, it is impossible that God be material in any sense since God is pure act and matter is in potentiality.

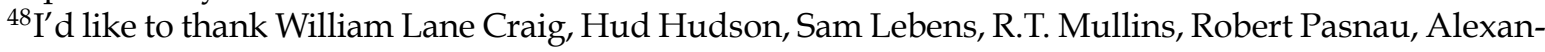
der Pruss, Josh Rasmussen, Michael Rea, and Philip Swenson in particular for their helpful comments and discussion. I owe a debt of appreciation and gratitude to The John Templeton Foundation as this project was completed during my time as a Templeton Postdoctoral Fellow at the University of Notre Dame, Center for Philosophy of Religion. A warm thanks to the Fellows, directors, and staff of the Center for helping make the 2013-2014 academic year productive and immensely rewarding, both personally and professionally. 


\section{References}

[1] Adams, Robert Merrihew. 1994. Leibniz: Determinist, Theist, Idealist. New York: Oxford University Press.

[2] Adams, Marilyn McCord. 2006. Christ and Horrors: The Coherence of Christology. New York: Cambridge University Press.

[3] Adams, Marilyn McCord. 2010. Some Later Medieval Theories of the Eucharist: Thomas Aquinas, Gilles of Rome, Duns Scotus, and William Ockham. Oxford: Oxford University Press.

[4] Anselm of Canterbury. 1998. Saint Anselm of Canterbury: The Major Works. Edited with an Introduction by Brian Davies and G.R. Evans. New York: Oxford University Press.

[5] Anselm of Canterbury. 2007. Anselm: Basic Writings. Edited and Translated by Thomas Williams. Indianapolis: Hackett Publishing Company.

[6] Thomas Aquinas. 1975. Summa Contra Gentiles. Trans. and ed. A. C. Pegis. Notre Dame: University of Notre Dame Press.

[7] Augustine. 1947. The Immortality of the Soul. Translated by Ludwig Schopp. New York: CIMA Publishing Company.

[8] Augustine. 1961. Confessions. Translated with an introduction by R.S. Pine -Coffin. Penguin Books.

[9] Augustine. 1991. On The Trinity. Vol. I/5. Introduction, translation and notes by Edmund Hill, O.P. Series edited by John E. Rotelle, O.S.A. Brooklyn, New York: New City Press.

[10] Augustine. 1994. Sermons, (273-305A) on the Saints. Vol. III/8. Translation and notes by Edmund Hill, O.P. Series edited by John E. Rotelle, O.S.A. Hyde Park, New York: New City Press.

[11] Augustine. 2004. Letters 156-210. Vol. II/3. Translation and notes by Roland Teske, edited by Boniface Ramsey. Hyde Park, New York: New City Press.

[12] Blount, Douglas Keith. 1997. “An Essay on Divine Presence.” Ph.D. diss, University of Notre Dame.

[13] Brower, Jeffrey. 2014. Aquinas's Ontology of the Material World: Change, Hylomorphism, and Material Objects. Oxford University Press.

[14] Carroll, John W. and Ned Markosian. 2010. An Introduction to Metaphysics. New York: Cambridge University Press. 
[15] Conn, Christopher H.. "Anselmian Spacetime: Omnipresence and the Created Order." The Heythrop Journal, LII, pp. 260-270.

[16] Craig, William Lane, J.P. Moreland. 2003. Philosophical Foundations for a Christian Worldview. Downers Grove, IL: InterVarsity Press.

[17] Crisp, Oliver. 2007. Divinity and Humanity. New York: Cambridge University Press.

[18] Cross, Richard. 2003. "Incarnation, Omnipresence, and Action at a Distance." Neue Zeitschrift fu?r Systematische Theologie und Religionsphilosophie, 45: 293-312.

[19] Descartes, Ren. 1985. The Philosophical Writings of Descartes, vol. iii, trans. John Cottingham, Robert Stoothoff, Dugald Murdoch, and Anthony Kenny. Cambridge: Cambridge University Press.

[20] Earman, John. 1989. World Enough and Spacetime. Cambridge: MIT Press.

[21] Edwards, Jonathan. 1955. The Philosophy of Jonathan Edwards From His Private Notebooks. Edited by Harvey G. Townsend. Eugene, Oregon: The University Press.

[22] Fine, Kit. 1994. "Essence and Modality." Philosophical Perspectives, Vol. 8, Logic and Language, pp. 1-16.

[23] Gilmore, Cody. 2003. "In Defense of Spatially Related Universals." Australasian Journal of Philosophy, Vol. 81, No. 3, pp. 420-428.

[24] Gilmore, Cody. 2014 "Location and Mereology", The Stanford Encyclopedia of Philosophy (Spring 2014 Edition), Edward N. Zalta (ed.), URL = <http://plato.stanford.edu/archives/spr2014/entries/location-mereology/>

[25] Goetz, Stewart and Taliaferro, Charles. 2011. A Brief History of the Soul, WileyBlackwell.

[26] Goris, H.J.M.J. 2009. “Divine Omnipresence in Thomas Aquinas.” In Divine Transcendence and Immanence in the Work of Thomas Aquinas, Leuven: Peeters, Publications of the Thomas Instituut te Utrecht, 2009, nr. 13, pp. 37-58.

[27] Grant, Edward. 1981. Much Ado About Nothing: Theories of Space and Vaccum from the Middle Ages to the Scientific Revolution, Cambridge: Cambridge University Press.

[28] Helm, Paul. 1980. “God and Spacelessness." Philosophy 55.

[29] Hoffman, Joshua, Gary S. Rosenkrantz. 2002. The Divine Attributes. Malden, MA: Blackwell Publishing. 
[30] Hudson, Hud. 2005. The Metaphysics of Hyperspace. New York: Oxford University Press.

[31] Hudson, Hud. 2009. "Omnipresence". In The Oxford Handbook of Philosophical Theology, edited by Thomas P. Flint, and Michael Rea. Oxford University Press.

[32] Hudson, Hud. 2014. The Fall and Hypertime. Oxford: Oxford University Press.

[33] Leftow, Brian. 1989. “Anselm on Omnipresence." The New Scholasticism 63 (3), pp. 326-357.

[34] Leibniz, Gottfried Wilhelm. 1989. Philosophical Papers and Letters. A Selection Translated and Edited, with an Introduction by Leroy E. Loemker. Netherlands: Kluwer Academic Publishers.

[35] Locke, John. 1975. Essay Concerning Human Understanding. Ed. and Trans. Peter H. Nidditch. Oxford: Clarendon.

[36] Lycan, William. 2009. "Giving Dualism its Due." Australasian Journal of Philosophy. Vol. 87, No. 4, pp. 551-563.

[37] Malebranche, Nicolas. 1997. Dialogues on Metaphysics and on Religion. N. Jolley and D. Scott, Trans. Cambridge: Cambridge University Press.

[38] Markosian, Ned. 2000. “What are Physical Objects?" Philosophy and Phenomenological Research, Vol. 61, No. 2 (Sep., 2000), pp. 375-395.

[39] McDaniel, Kris. 2004. "Modal Realism with Overlap." Australasian Journal of Philosophy 82.1, pp. 137-152.

[40] McDaniel, Kris. 2007. “Extended Simples.” Philosophical Studies, 133: 131-141.

[41] McDaniel, Kris. 2009. "Structure-Making." Australasian Journal of Philosophy 87.2: 251-274.

[42] Molnar, George. 2003. Powers: A Study in Metaphysics. New York: Oxford University Press.

[43] More, Henry. 1995. Manual of Metaphysics [Manual], trans. Alexander Jacob Hildesheim: Georg Olms.

[44] Muller, Richard A.. 2003. Post-Reformation Reformed Dogmatics: The Divine Essence and Attributes, Volume 3. Grand Rapids, MI: Baker Academic.

[45] Newton, Isaac. 1934. Mathematical Principles of Natural Philosophy, Andrew Motte and Florian Cajori, trans. Berkeley: University of California Press. 
[46] Newton, Isaac. 1962. Unpublished Scientific Papers of Isaac Newton. Cambridge: Cambridge University Press.

[47] Newton, Isaac. 1999. The Principia. Transalted by I. Bernard Cohen and Anne Whitman. Berkeley: University of California Press.

[48] Oakes, Robert. 2006. "Divine Omnipresence and Maximal Immanence: Supernaturalism versus Pantheism." American Philosophical Quarterly, Vol. 43, No. 2, pp. 171179

[49] Ockham, William. 1991. Quodlibetal Questions. Translated by Alfred J. Freddoso and Francis E. Kelly. New York: Yale University Press.

[50] O'Leary-Hawthorne, John and Jan Cover. 1998. "A World of Universals." Philosophical Studies 91: 205-219.

[51] Parsons, Josh. 2000. "Must a Four-Dimensionalist Believe in Temporal Parts?" The Monist, 83: 399-418.

[52] Parsons, Josh. 2007. "Theories of Location." Oxford Studies in Metaphysics, vol. 3., pp. 201-232.

[53] Parsons, Josh. “Entension." Unpublished manuscript.

[54] Pasnau, Robert. 2011a. “On Existing All at Once." In C. Tapp and E. Runggaldier (eds.) God, Eternity, and Time. Burlington: Ashgate, 11-29

[55] Pasnau, Robert. 2011b. Metaphysical Themes 1274-1671. Oxford: Clarendon Press.

[56] Pruss, Alexander. 2013. “Omnipresence, Multilocation, the Real Presence and Time Travel." Journal of Analytic Theology, Vol. 1, No. 1, May 2013.

[57] Reid, Jasper William. 2008. “The Spatial Presence of Spirits among the Cartesians." Journal of the History of Philosophy, Volume 46, Number 1, January 2008, pp. 91-117.

[58] Schaff, Philip (ed.) . 1877. Creeds of Christendom, 4th edn. New York: Harper and Bros.

[59] Simons, Peter. 2004. "Extended Simples: A Third Way Between Atoms and Gunk." The Monist, 87: 371-84.

[60] Stump, Eleonore. 2010. Wandering in Darkness. New York: Oxford University Press.

[61] Stump, Eleonore. 2013. "Omnipresence, Indwelling, and the Second Personal." European Journal for Philosophy of Religion, Volume 4, Number 4, pp. 29-53.

[62] Swinburne, Richard. 1993. The Coherence of Theism. New York: Oxford University Press. 
[63] Swinburne, Richard. 1994. The Christian God. Oxford: Clarendon Press.

[64] Taliaferro, Charles. 1994. Consciousness and the Mind of God. Cambridge: Cambridge University Press.

[65] Tappert, Theodore G. (trans. and ed.). 1959. The Book of Concord: The Confessions of the Evangelical Lutheran Church. Philadelphia: Fortress Press.

[66] Turretin, Francis. 1992. Institutes of Elenctic Theology, ii, trans. George Musgrave Giger, ed. James T. Dennison Jr. Phillipsburg: P\&R Publishing Co.

[67] Van Den Brom, Luco J. 1993. Divine Presence in the World: A Critical Analysis of the Notion of Divine Omnipresence. Kampen, Netherlands: Kok Pharos Publishing House.

[68] van Inwagen, Peter. 1990. Material Beings. Ithica: Cornell University Press.

[69] Wainwright, William J.. 2009. "Omnipotence, Omniscience, and Omnipresence." The Cambridge Companion to Christian Philosophical Theology. 1st ed. Cambridge: Cambridge University Press, pp. 46-65.

[70] Wayne, Andrew. 2008. "A Trope-Bundle Ontology for Field Theory." The Ontology of Spacetime. Volume 2. The Netherlands: Elsevier.

[71] Wesley, John. 1991. John Wesley's Sermons: An Anthology. Edited by Albert C. Outler. Nashville: Abingdon Press.

[72] Wierenga, Edward. 1988. “Anselm on Omnipresence." The New Scholasticism. 62 (1), pp. 30-41.

[73] Wierenga, Edward. 2010. “Omnipresence." In A Companion to Philosophy of Religion. Edited by Charles Taliaferro, Paul Draper, and Philip L. Quinn. Malden, MA: Blackwell Publishing.

[74] Williams, Thomas. 2007. Anselm: Basic Writings. Translated and Edited by Thomas Williams. Indianapolis: Hackett Publishing Company.

[75] Zagzebski, Linda. 2013. Omnisubjectivity: A Defense of a Divine Attribute. Milwaukee: Marquette University Press. 